\title{
FUNDAMENTALISME DAN RADIKALISME DALAM PUSARAN KRISIS POLITIK DI TIMUR TENGAH
}

\author{
Abdurrohman Kasdi \\ IAIN Kudus, Jl. Conge Ngembalrejo Kudus 59322 \\ abdurrohmankasdi@stainkudus.ac.id
}

\begin{abstract}
Abstrak
Artikel ini mengkaji tentang eksistensi fundamentalisme dan radikalisme dan pengaruhnya dalam krisis politik di Timur Tengah. Metode yang digunakan adalah kualitatif dengan pendekatan sosiologi agama dan pendekatan sejarah. Menggunakan pendekatan sosiologi agama, karena studi tentang fundamentalisme dan radikalisme sangat terkait dengan agama-agama. Selain itu, juga menggunakan pendekatan sejarah, karena mengkaji politik timur tengah sangat berkaitan dengan latar belakang sejarah, sosial, politik, budaya, ekonomi dan lain sebagainya. Hasil penelitian menunjukean bahwa krisis politik di Timur Tengah dapat dianalisis dalam tiga hal: pertama, konflik antara negara-negara Arab dengan Israel. Kedua, konflik dalam internal Negara Arab. Ketiga, konflik negara-negara non Arab di Wilayah Timur Tengah. Krisis politik ini disebabkan oleb beberapa faktor, yaitu: pertama, masalah perbatasan(boundary dispute). Pada tabun 1916, melalui perjanjian Sykes-Picot, Inggris dan Perancis melakukan negoisasi membagi bekas wilayah Turki Utsmani; Irak, Libanon, Suriah, dan Yordania. Kedua, Masalah Minyak. Minyak menjadi salah satu faktor munculnya isu sentral yang sangat sensitif dan selalu menjadi pemicu adanya konflik di TimurTengah. Ketiga, Masalah Air. Air menjadi
\end{abstract}


salah satu sumber vital kehidupan manusia, sehingga banyak sekali konflik yang terjadi di kawasan Timur-Tengah yang disebabkankan oleh air. Sedangkan fundamentalisme dan radikalisme agama di Timur Tengah dapat diklasifikasikan dalam beberapa kategori. Pertama, negara-negara yang rezim pemerintahnya otoriter seperti Irak dan Suriah. Kedua, wilayah yang dijajah dan diduduki kekuatan asing, seperti di Palestina. Ketiga, di negara yang kebijakan pemerintahannya dipandang terlalu memibak ke Barat seperti di Mesir.

Kata Kunci: Fundamentalisme,Radikalisme, Krisis Politik, Timur Tengah.

\section{A. Pendahuluan}

Dalam dekade terakhir ini, kawasan Timur Tengah sedang menghadapi krisis politik yang paling serius dalam sepanjang sejarah. Konflik Israel dan Palestina yang telah berlangsung bertahun-tahun, serta puncaknya setelah pengumuman pengakuan Amerika Serikat (AS) atas Yerusalem sebagai ibu kota Israel pada tanggal 8 Desember 2017. AS bersikeras mempertahankan keputusan itu dengan menggunakan veto di Dewan Keamanan PBB dan mengabaikan sisi keadilan dan perasaan rakyat Palestina. Percobaan Kudeta terhadap Erdogan di Turki yang terjadi pada tanggal 15 Juli 2016 dan menimbulkan berbagai reaksi di seluruh penjuru dunia. Konflik Suriah antara Pemerintah Basyar alAsyad dengan pemberontak telah melahirkan friksi politik di kawasan Timur Tengah saat ini. Kemudian Libanon yang juga mengalami krisis politik akibat mundurnya Perdana Menteri Libanon, Saad Hariri, dari kursi kekuasaannya.

Krisis politik paling mutakhir melanda Timur Tengah setelah beberapa negara di kawasan tersebut memutuskan hubungan diplomatik dan mengisolasi Qatar. Dimulai pemerintah Arab Saudi, Bahrain, dan kemudian diikuti oleh Uni Emirat Arab, serta Mesir memutuskan hubungan diplomatik dengan Qatar pada hari Senin, 5 Juni 2017. Negara-negara tersebut mengambil langkah demikian dengan alasan Qatar telah mendukung aksi terorisme. Hanya dalam waktu beberapa hari saja, serentetan 
negara Arab memutuskan hubungan diplomatik dengan Qatar, untuk memprotes negara tersebut yang memberikan dukungan secara politik, komunikasi dan keuangan kepada organisasiorganisasi teroris. Memberikan sanksi, dengan memutus hubungan diplomatik Qatar karena Qatar mendukung organisasi teroris hanyalah alasan untuk mengisolasi negara ini, yang akrab dengan Iran dan organisasi Ikhwanul Muslim.

Krisis politik ini merupakan dampak dari ketegangan di Timur Tengah yang terakumulasi dalam waktu yang panjang. Peristiwa-peristiwa yang mencerminkan krisis politik di Timur Tengah ini juga mencerminkan betapa kompleksnya persoalan yang dihadapi di kawasan Timur Tengah dan semakin tingginya potensi konflik yang ada di wilayah Timur Tangah.Kondisi tersebut semakin akut karena lemahnya kemampuan pemerintahnegaranegara Timur Tengah untuk mewujudkan tatanan nasional dan regional yang bisa mengakomodir perbedaan dan mengatur kepentingan yang beragam secara damai di kawasan Timur Tengah. Negara-negara di Timur Tengah berbagi dalam banyak hal, mereka memiliki beberapa kesamaan tetapi juga memiliki perbedaan yang tidak sedikit. Fenomena inilah yang menjadikan kajian tentang krisis politik di Timur Tengah menarik untuk dilakukan, apalagi jika dikaitkan dengan persoalan fundamentalisme dan radikalisme.

\section{B. Kajian Teori}

Salah satu fenomena paling menarik di abad ini, menurut Karen Armstrong, adalah munculnya gejala fundamentalisme dalam tradisi keagamaan. Munculnya gerakan fundamentalisme dalam agama, bukanlah sesuatu yang muncul secara mendadak. Kelahirannya disebabkan oleh berbagai macamlatar belakang sosial budaya yang melingkupi agama yang bersangkutan (Armstrong, 2001: 1).

Menurut Taylor, kaum fundamentalis adalah kelompok orang yang melakukan pendekatan konservatif dalam melakukan reformasi keagamaan, bercorak literalis, dan menekankan pada 
pemurnian doktrin (Taylor, 1988: viii). Sedangkan menurut Bannerman, kaum fundamentalis adalah kelompok ortodoks yang bercorak rigit dan ta'ashub (fanatik), yang bercita-cita untuk menegakkan konsep-konsep keagamaan zaman klasik dari abad ketujuh Masehi (Bannerman, 1988: 156). Bassam Tibbi bahkan memaknai fiundamentalisme lebih tegas, yaitu aliran keagamaan yang menolak segala hal yang baru, selain apa yang ada dalam doktrin (Tibi, 1988: 143).

Dari definisi di atas, tampak bahwa fundamentalisme merupakan aliran keagamaan yang sangat tekstualis dan rigit. Pergulatan internal atas kitab suci yang terjadi dalam tradisi keagamaan kemudian melahirkan kaum fundamentalis dan radikalis yang menginterpretasikan teks secara rigit dan kaku. Selain itu, beberapa kajian juga telah mengelaborasi beberapa ciri fundamentalisme, di antaranya apa yang dilakukan oleh Leonard Binder. Ia menyebutkan bahwa ciri utama fundamentalisme adalah pandangannya yang khas mengenai ijtihad. Menurut kaum findamentalis, ijtihad sangat terbatas dalam hal-hal yang tidak dibahas oleh syari'ah. Sedangkan ijtihad yang diakui sebagai salah satu sumber hukum Islam hanya ijtihad pada zaman sahabat Nabi, dan tidak boleh dihapuskan oleh ijtihad generasi setelahnya (Binder, 1961: 71).

Ciri kaum fundamentalis ini juga tergambar dari kecenderungan penafsiran mereka terhadap teks-teks suci yang juga bercorak rigit dan literalis. Mereka memandang bahwa teksteks agama bersifat total dan menyeluruh. Semua permasalahan dalam kehidupan manusia sudah tercakup di dalamnya. Oleh karena itu dengan sendirinya ijtihad sangat dibatasi di kalangan mereka. Mereka pun menganggap bahwa era awal Islam merupakan acuan yang mengikat secara keseluruhan. Konsekuensinya, kaum fundamentalis memandang pesimis dan negatif setiap produk baru, terutama yang diciptakan oleh Barat.

Selain Leonard Binder, Fazlur Rahman juga menambahkan beberapa ciri lain dari fundamentalisme, yaitu elan vital semangat 
anti Barat. Menurut Rahman, kaum fundamentalis senang dengan slogan-slogan yang bercorak distinktif, namun mereka pada hakikatnya merupakan kelompok yang anti intelektual. Karena pemikiran mereka tidak berakar dari al-Qur'an dan budaya intelektual tradisi Islam. Semangat anti Barat yang didengungkan oleh kaum fundamentalis terlihat bagaimana pandangan mereka dalam menyikapi modernisme dan semua produk Barat, semua ditolak oleh mereka (Rahman, 1979: 169).

Secara historis, istilah fundamentalisme muncul pertama kali sebagai upaya untuk memahami gejala perkembangan di lingkungan Kristen Protestan dan Katolik. Fundamentalisme lahir dalam situasi konflik antara masyarakat urban dan masyarakat pedesaan dalam sejarah Amerika Serikat pada saat Perang Dunia I. Pemimpin yang populer pada waktu itu adalah seorang tokoh agraris, W.J. Bryan. Konflik tersebut muncul bersamaan dengan situasi depresi nilai-nilai agraris dalam proses industrialisasi dan urbanisasi di negeri itu. Istilah fundamentalisme ini kemudian dipopulerkan oleh kaum Protestan Amerika sebagai perlawanan terhadap kaum liberal yang menurut mereka telah merusak keimanan orang-orang Kristen (Armstrong, 2001: x). Dalam tradisi Protestan, kelompok fundamentalis muncul sebagai respon atas gerakan kaum modernis yang mencoba melakukan pembacaan kritis terhadap Bible, bahkan sampai pada tingkat meragukan Bible.

Di lingkungan Islam Arab, fundamentalisme muncul setelah adanya kekalahan militer Arab di tangan bangsa Israel pada perang Juni 1976. Menurut Bassam Tibi, kekalahan itu mengantar dunia Arab dalam kubangan konflik yang berkepanjangan dan memunculkan kelompok fundamentalis di kalangan mereka(Tibi, 2000: xv). Sedangkan fundamentalisme Yahudi muncul akibat mereka terlalu kaku dalam memahami doktrin agama mereka. Bahkan fundamentalisme agama tidak hanya terdapat pada agama monoteisme saja. Ada juga fundamentalis Budha, Hindu dan bahkan Kong $\mathrm{Hu} \mathrm{Cu}$, yang sama-sama menolak butir-butir nilai budaya liberal, saling berperang atas nama agama (Tuhan), dan 
berusaha membawa hal-hal yang sakral ke dalam urusan politik dan negara.(Armstrong, 2001: x-xi)

Menurut Fazlur Rahman, asal mula munculnya fundamentalisme merupakan reaksi terhadap Barat, sekulerisme dan modernisme. Akar intelektual kaum fundamentalisme berasal dari gagasan reformasi pra modern, terurtama paham reformis kaum Wahabi di Arab Saudi, yang sangat rigit dalam memahami alQur'an dan sunnah. Mereka juga bersikap keras terhadap gagasan yang berseberangan dengan ortodoksi dalam tradisi pemikiran mereka (Rahman, 1979: 162).

Kaum fundamentalis berusaha menolak eksistensi negarabangsa, berdasarkan perbedaan geografis, bahasa, warna kulit dan budaya. Mereka juga menolak gagasan tentang pluralisme dan semua budaya yang berasal dari Barat. Sehingga, gerakan yang dilakukan oleh kaum fundamentalis sebenarnya memiliki beberapa karakter, yaitu: pertama, perlawanan terhadap semua bentuk dominasi yang dilakukan oleh Barat. Kedua, fundamentalisme agama mempunyai agenda politisasi agama yang agresif dalam semua lini kehidupan. Ketiga, fundamentalisme dan radikalisme, baik dalam tradisi keagamaan Kristen, Islam, Yahudi maupun agama lain, merupakan bentuk superfisial dari terorisme agama (Tibi, 2000: x).

Mereka mengembangkan jaringan, melakukan rekrutmendan kaderidsasi selama beberapa dekade, dengan menghimpun dana, merekrut anggota baru, melatih milisi, mendoktrin dan menyebarkan ajaran merekadengan misi untuk melawan Barat dan kekuatan sekuler.Kebangkitan kaum fundamentalis dimulai sejak lengsernya Shah Iran Reza Pahlevi, yang kemudian ditandai dengan tampilnya Imam Khoemaini sebagai pemimpin Revolusi Iran tahun 1979 (Sahrasad \& al-Chaidar, 2017: iv-v). Disusul pada fase berikutnya, terjadinya pergolakan di Mesir, Saudi Arabia, Syria, Pakistan, Afghanistan, dan negara-negara lain di Timur Tengah.

Setidaknya ada empat dimensi untuk melacak asal-usul fundamentalisme, yaitu: faktor psikologi, sosial, politik, dan 
sejarah. Secara psikologis, adanya sikap dogmatik, alienasidan ketidakdewasaan dalam memahami ajaran agama. Faktor sosial politik di antaranya pengaruh dominasi asing, konflik sosial politik, krisis legitimasi pemerintah, serta ketidakmampuan masyarakat dan negara dalam beradaptasi sekaligus menghadapi perubahan yang sangat cepat. Sedangkan faktor sejarah, fundamentalisme bisa dilacak mulai dari kehadiran kelompok Khawarij yang yang memiliki kecenderungan dogmatis sangat kuat. Dari kelompok ini juga yang melakukan pembunuhan terhadap Khalifah Ali bin Abi Thalib. Faktor sejarah ini meskipun terjadi pada awal-awal Islam, namun telah memberikan pengaruh yang besar bagi munculnya fundamentalisme.

Karakteristik kaum fundamentalis mempunyai titik temu dengan kaum radikalis dalam meneriakkan slogan-slogan revolusioner dan memaknai jihad dalam menegakkan hukum Allah. Kaum fundamentalis dan kaum radikalis lebih cenderung bersikap doktriner dalam menyikapi persoalan yang mereka hadapi, namun tidak menggunakan pemikiran yang rasional dan intelektual.Fundamentalisme dalam hal ini bisa ditarik dalam dua kelompok: yaitu fundamentalisme yang mengikuti model Wahabi dan fundamentalisme yang mengikuti model Syi'ah.

Secara ideologi, kaum fundamentalis dan kaum radikalis mempunyai kesamaan dalam beberapa hal, di antaranya; pertama, mereka meniscayakan hubungan yang harmonis antara agama dan negara (Al-Jabiri, 1996: 115), terutama terbentuknya lembaga dan institusi yang berlabelkan pada Islam. Seperti isu formalisasi syariat Islam, negara Islam, mempermasalahkan gender dan simbol-simbol ideologi keagamaan lainnya. Kedua, sikap kaum fundamentalis dan kaum radikalis sangat stigmatis terhadap Barat. Dalam image mereka, Barat tampil sebagai monster imperalis yang sewaktuwaktu mengancam akidah dan eksistensi mereka. Dialog Islam dan Barat selalu mengalami kebuntuan. Arah politik luar negeri kaum radikalis sengaja diarahkan sebagai pemberontakan dan menggugat dominasi Barat (Giddens, 1987: 255). Ketiga, deklarasi perang 
terhadap paham sekuler. Kaum fundamentalis dan kaum radikalis berjuang keras untuk memerangi dan meruntuhkan tatanan yang sekuler tentang lembaga politik dan bermaksud menggantikannya dengan tatanan Tuhan.

Sedangkan dalam gerakan, fundamentalisme dan radikalisme akan berbenturan dengan demokrasi, egaliter, gender, HAM dan isu lainnya. Sayyid Quthb misalnya, ia sangat keras menentang setiap gagasan mengenai kedaulatan rakyat. Menurutnya, hal itu bertentangan dengan kekuasaan Tuhan yang menguasai manusia dalam setiap bentuk, sistem dan kondisi. Pendapat ini diperkuat oleh Syaikh Fadlallah Nuri. Menurutnya, inti dari gagasan demokrasi, yakni kesamaan dan kedudukan semua warga negara, sangat mustahil diterapkan di negara muslim. Penolakan kaum radikalisme terhadap kedaulatan rakyat dan negara-bangsa, bukan hanya karena ia merupakan solusi yang diimpor (al-hulûl al-Mustauradah) (Al- Qardawi, 1980: 49), sebagaimana yang diungkapkan oleh Yusuf al-Qardlawi, tetapi juga karena lebih mencerminkan prototype negara sekuler. Konsep ini, menurut mereka bertentangan dengan jargon politik Islam, formalisasi syariat Islam hukum keadilan Tuhan, dan konsep syurâ.

Fundamentalisme Islam merupakan bentuk ekstrim dari gejala revivalisme. Jika revivalisme dalam bentuk intensifikasi keislaman yang berorientasi ke dalam (inward oriented), maka fundamentalisme juga mengarahkan pada orientasi ke luar (outward oriented). Fundamentalisme menjelma menjadi kelompok yang mempunyai komitmen yang tinggi, baik dalam hal transformasi kehidupan individua, maupun kehidupan komunal dan sosial (Azra, 1996: 107-108). Fundamentalisme Islam juga sangat memperhatikan hal-hal yang bersifat eksoteris, hitam-putih dan menegaskan kebolehan dan tidaknya sesuatu hanya berdasarkan pada teks semata.

Maka dari itu, fundamentalisme dan radikalisme menjadi tantangan besar bagi negara-bangsa, yang mempunyai misi membentuk nation-building yang inklusif. Karena mereka akan 
menggunakan kekerasan dalam upaya untuk merealisasikan agenda mereka, seperti penembakan brutal kelompok ekstrim dan fundamentalis Yahudi terhadap ratusan warga Muslim Palestina yang sedang melakukan shalat subuh di Masjid al-Khalil (Hebron), yang menewaskan 63 orang, serangan kamikaze terhadap Gedung WTC dan Pentagon yang mengejutkan dunia dan peristiwa lain yang terekam dalam aksi mereka (Kasdi, 2002: 19-20).

\section{Metode Penelitian}

Penulisan artikel ini menggunakan metode kualitatif dengan pendekatan sosiologi agama dan pendekatan sejarah (D. Abdurrahman, 2007: 21), untuk mengkaji fundamentalisme dan radikalisme dalam pusaran krisis politik di Timur Tengah. Metode kajian yang dipakai adalah metode kajian analitis. Metode ini bermaksud menjelaskan hakikat fakta tertentu, mengapa suatu fakta terjadi, peran dan bagaimana hubungannya dengan fakta yang lain. Dengan memilih pendekatan dan metode kajian tersebut diharapkan fenomena yang ditemukan di lapangan terkait fundamentalisme dan radikalisme dapat diinterpretasikan isi, makna dan esensinya secara lebih mendalam. Dengan demikian, kajiannya bersifat holistik dengan mendudukkan objek penelitian dalam suatu konstruksi yang utuh (Muhajir, 1994: 13).

Metode yang digunakan adalah kualitatif karena data yang terkumpul dan analisisnya bersifat kualitatif. Penelitian kualitatif lebih bersifat deskriptif, yakni data yang terkumpul berbentuk kata atau gambar, tidak menekankan pada angka(Sugiono, 2008: 9). Sebagaimana juga dikatakan oleh W. Lawrence Neuman, 'Descriptive research presents a picture of specific detail of situation, social setting or relationship." (Neuman, 1997: 20) Pendekatan yang digunakan adalah pendekatansosiologi agama, karena studi tentang fundamentalisme dan radikalisme sangat terkait dengan agama-agama. Selain itu, juga menggunakan pendekatan sejarah, karena mengkaji politik timur tengah sangat berkaitan dengan latar belakang sejarah, sosial, politik, budaya, ekonomi dan lain sebagainya. 


\section{Hasil Penelitian dan Pembahasan}

\section{Genealogi dan Sejarah Konflik di Timur Tengah}

Timur Tengah merupakan kawasan yang sangat dinamis, cepat mengalami perubahan baik secara definisi maupun kebijakan politik. Mendefinisikan istilah Timur Tengah saja masih belum ditemukan kesepakatan di antara para pakar, negara-negara mana saja yang masuk dalam kawasan ini. Bahkan dikalangan pakar politik internasional belum ada kesamaan mengenai maknaTimur Tengah;baikmengenai bangsa, negara dan wilayah mana yang dapat dimasukkan dalam kategori kawasan Timur-Tengah (Sihbudi, 2007: xxi-xxii).

Definisi Timur Tengah dewasa ini mengalami pergeseran dari sebelumnya, sebagaimana yang diungkapkan oleh Dr. Muhammad Sya'ban dalam Koran harian nasional "al-Ahram", yang diistilahkannya dengan Timur Tengah Raya (Sya'ban, 1998). Timur Tengah menurut deinisi ini, meliputi: negara-negara barat Arab dan timur Arab, diantaranya Turki, Israel, negara-negara Teluk, termasuk Iran, juga sebagian wilayah yang tersebar di belahan Kaukasus, Asia Tengah sampai pada negara-negara yang membentang sekitar Laut Tengah. Hal ini berbeda dengan definisi lama yang hanya meliputi negara-negara Arab saja (Kasdi, 2001: 126).

Di negara-negara kawasan Timur Tengah ini akan terus lahir berbagai konflik baru, dimana Amerika Serikat dan Rusia akan selalu memegang peranan penting. Belakangan Cina juga memainkan peran strategis di kawasan ini, terutama di sektor ekonomi. Sebagai contoh, Amerika Serikat memandang Timur Tengah Raya sebagai ajang intervensi militernya mulai tahun 1979 sampai sekarang, antara lain Operasi Militer di Iran tahun 1979, pengerahan militer di Libanon 1982, serangan ke Libia tahun 1986, Proteksi transfer minyak dan pengibaran bendera Amerika Serikat pada tahun 1987-1988, terjadinya perang teluk 1990-1991, dan operasi militer lain yang berkelanjutan di wilayah Timur Tengah ini. 
Sengketa di Timur Tengah sebenarnya hanya berpangkal pada satu inti permasalahan, yaitu antara Arab dan Israel. Namun, satu inti tersebut kemudian melahirkan banyak persengketaan lain. Sengketa di antara negara-negara di Timur Tengah dapat dianalisis dalam tiga hal: pertama, konflik antara negara-negara Arab dengan Israel. Kedua, konflik dalam internal Negara Arab. Dan ketiga, konflik negara-negara non Arab di Wilayah Timur Tengah. Genealogi konflik dan sengketa di Timur Tengah terletak pada kekuatan nasional dan regional. Hal ini tampak dari tiga kekuatan nasional; yaitu: kekuatan nasional Turki, kekuatan nasional Arab dan kekuatan nasional Persia, termasuk kekuatan-kekuatan regional yang menghimpun semua kekuatan nasional tersebut. Denganberdirinya negara Israel, hal ini menambah sumber persengketaan yang lain, khususnya kaum zionis yang memaksakan faham nasional mereka dan memposisikan diri secara antagonis dengan kekuatan nasional di Arab dan Timur Tengah.

Negara Iran yang mempunyai soliditas tinggi pasca Revolusi Iran, merasa terancam keamanan dan kedaulatannya oleh eksistensi Israel. Sejak dideklarasikannya negara Israel pada tahun 1948, negara-negara Arab yang lain juga selalu dihantui oleh rasa ketakutan. Sementara negara Turki mendirikan pakta militer dengan Israel, yang menambah kekhawatiran negara-negara Arab di kawasan Timur Tengah. Sementara Israel, dengan alasan untuk membentuk keamanan di kawasan regional, mereka berusaha menggandeng Yordania kedalam pakta integritas Turki dan Israel. Negara Irak merasa khawatir jika ternyata Turki menjadi tempat transit dan sarana bagi Israel untuk memasukkan pengaruhnya ke Irak. Turki juga merasa khawatir dengan negara-negara Arab, apabila mengalihkan benih perengketaan mereka dengan Israel ke wilayah Turki.

Irak mempunyai beban sejarah dengan Iran, pada saat Saddam Hussein menandatangani pakta integritas dengan Syah Iran tahun 1975, dengan menyerahkan Garis Demarkasi Shatt al-Arab ketangan Iran. Waktu itu Saddam menerima perjanjian, karena 
melihat Irak sebagai pihak yang kalah kuat dibandingkan dengan Iran di zaman Syah Iran. Karena itu, ketika Ayatullah Khomeini sedang asyik melakukan konsolidasi revolusi Islamnya yang baru berumur Sembilan belas bulan dan masih menghadapi tekanan berat dari Amerika, Eropa dan masyarakat Internasional, tiba-tiba Irak dengan komando Saddam melakukan agresi ke Iran yang dimulai pada 9 september 1980. Agresi ini merupakan serangan kilat dengan maksud untuk melumpuhkan kekuatan Iran yang sedang mengalami pembenahan di dalam negeri. Sehingga Irak dengan waktu singkat dapat menduduki kawasan yang membentang dari Qasri-Syirin sampai Ilam dan mengepung pangkalan udara Iran di Kermansyah, menyerbu Syatt al-Arab, Abadan, Ahwaz, Khuramsar dan Dizful. Namun, berkat konsolidasi dari pemerintah Khomeini, sedikit demi sedikit tentara Irak dapat dihalau dan akhirnya kembali ke Irak.

Irak juga mempunyai permasalahan dengan Kuwait, mengenai daerah Kuwait yang diklaim oleh Irak sebagai wilayahnya. Mesir mempunyai potensi konflik dengan Sudan. Disatu sisi pemerintah Sudan menuduh Mesir sebagai dalang dibalik pemberontakan di daerah Sudan Selatan. Sementara Mesir menuduh pemerintah Sudan telah merekayasa penembakan Husni Mubarak, Presiden Mesir, dalam perjalanan Mesir-Sudan. Puncak konflik ini adalah terputusnya hubungan diplomatik antara kedua negara untuk beberapa waktu. Bahkan, Sudan pernah mengancam akan meracuni Sungai Nil yang merupakan sumber air utama bagi masyarakat Mesir yang berasal dari Sudan dan wilayah Afrika.

Demikian juga, konflik Palestina-Arab dengan Israel yang tak pernah diketahui kapan berhentinya. Dari tiga kali peperangan besar Israel dengan Arab (1948, 1967 dan 1973), wilayah pendudukan Israel atas wilayah-wilayah Arab semakin bertambah saja. Sebab, dalam peperangan tersebut negara Arab selalu kalah menghadapi Israel yang dibantu AS. Dalam perang 1948 misalnya, negara Arab dipermalukan oleh Israel (Lenezowski, 1993: 257). Menyusul 1967, seluruh daerah Palestina seperti West Bank, termasuk Yerusalem Timur dan Gaza, diduduki Israel. 


\section{Krisis Politik di Timur Tengah}

Dalam dekade terakhir ini, kawasan Timur Tengah sedang menghadapi krisis politik yang paling serius dalam sejarah. Krisis politik ini merupakan akibat dari ketegangan dan gesekan politik yang terakumulasi dalam rentang waktu yang panjang di kawasan Timur Tengah. Dalam menghadapi situasi krisis politik di Timur Tengah ini, masyarakat internasional sedang berupaya untuk meredakan ketegangan, menghimbau kepada semua pihak supaya tenang memecahkan perselisihan melalui dialog yang melibatkan semua unsur negara-negara yang ada di kawasan tersebut.

Krisis politik dan beberapa konflik di Timur-Tengah disebabkan oleh beberapa faktor, yaitu: pertama, masalah perbatasan (boundary dispute). Pada tahun 1916, melalui perjanjian Sykes-Picot, Inggris dan Perancis melakukan negoisasi membagi bekas wilayah Turki Utsmani; Irak, Libanon, Suriah, dan Yordania. Inggris menguasaiwilayah Irak dan Yordania, sementara Perancis menguasai Suriah dan Libanon. Demikian juga pada tahun 1917 Inggris memberikan wilayah Palestina untuk Israel melalui Deklarasi Balfour, yang kemudian menjadi sumber konflik hingga saat ini di kawasan Timur Tengah. Adanya kesulitan menentukan batas wilayah daratan dikarenakan kondisi geografis yang berpadang pasir, dan juga sulitnya menentukan perbatasan daratan yang mencapai pantai seperti di Libya,Mesir, dan Tunisia dan konflik Aljazair-Maroko memperebutkan Sahara Barat.

Kedua, Masalah Minyak. Minyak menjadi salah satu faktor munculnya isu sentral yang sangat sensitif dan selalumenjadi pemicu adanya konflik di Timur-Tengah,terutama di wilayah Asia Barat.Konflik ini kemudian melebar menjadi konflik regional dan konflik internasional yang melibatkan pihak-pihak asing yang berkepentingan. Minyak merupakan komoditas penting bagi masyarakat Timur Tengah, namun sekaligus menimbulkan kegelisahan. Karena ia menjadi komoditas satu-satunya sebagai kekuatan bargaining yang dimiliki negara-negara Timur Tengah sekaligus untuk memenuhi kebutuhan rakyatnya. Minyak juga 
menjadi daya tawar di dunia internasional (Abdurrahman, 2003: 61). Konsentrasi minyak di Timur Tengahpada umumnya berada di daerah yang mempunyai potensi konflik; contohnya Kota Kirkuk di Irak Utara adalah tempat cadangan minyak Irak terbesar, dimana di daerah itu merupakan basis dari suku Kurdi yang sedang menginginkan kemerdekaan dari Pemerintah Irak.

Ketiga, Masalah Air. Air merupakan sumber utama kehidupan manusia, sehingga banyaksekali konflik yang terjadi di kawasan Timur Tengah yang disebabkankan oleh air (Moris, 1997: 1-13). Air menjadi komoditas untuk pemenuhan kebutuhan hidup sehari-hari yang keberadaannya sangat terbatas di kawasan Timur Tengah. Boutros Boutros Ghali memprediksi bahwa suatu saat air akan menjadi komoditi yang lebih berharga daripada minyak, dan negara-negara Timur Tengah suatu saat akan berperang demi air (Starr, 1992: 64). Di Timur Tengah yang terdiri dari kurang lebih 20 negara, ternyata hanya memiliki 4 sungai besar sebagai sumber kehidupannya, yaitu Sungai Nil, Sungai Yordan, Sungai Eufrat dan Tigris. Problemnya adalah adanya keterbatasan sumber air tawar dan sungai tersebut juga mengalir melewati beberapa negara.

Sering terjadi konflik karena sebagian negara membangun dam dan waduk di negaranya yang mengakibatkan jumlah aliran sungai dan debit air ke negara lain menjadi berkurang. Contohnya seperti pemerintah Turki yang membangun bendungan Attaturk yang kemudian memicu konflik antara Turki, Irak, Iran, dan Suriah atas pemanfaatan aliran air Sungai Eufrat dan Tigris. Demikian juga Suriah, yang membangun bendungan al-Thawra pada tahun 1975 yang debit airnya ditampung di Danau al-Asad. Kebijakan pemerintah Suriah ini mengakibatkan hubungan politiknya dengan pemerintah Irak menjadi tegang, karena debit air sungai Eufrat dan Tigris secara otomastis menjadi berkurang di Irak dan kondisi ini tentu saja mengancam kehidupan rakyat Irak (Ruslin, 2013)

Selain tiga hal di atas, menurut Leslie Lipson, faktor penyebab utama krisis politik di Timur Tengah adalah meratanya perpecahan yang akut dalam masyarakat Timur Tengah, yang 
berasal dari tribalisme dan ganasnya sektarianisme agama (Lipson, 1993: 278). Kaum radikalis telah memberikan kontribusi terhadap panasnya eskalasi konflik dan meningkatnya krisis di negara-negara Timur Tengah. Analisis Leslie Lipson ini diperkuat oleh Michael Hudgson. Menurutnya, pusat identitas bangsa Arab terletak pada dimensi budaya, bahasadan agama, yakni Islam. Muslim di Timur Tengah mayoritas adalah Sunni. Sehingga dengan batasan ini, muslim sunni non-Arab, seperti suku Kurdi dan Barbar serta muslim Arab non-Sunni, seperti kaum Alawi, Druze dan beberapa cabang Islam Syi'ah tidak diperhitungkan.

Dalam dekade terakhir, ada beberapa peristiwa terkait krisis politik di Timur Tengah yang paling mutakhir,yaitu: pertama, perang saudara di Suriah yang melibatkan pemerintah dan oposisi. Banyak aktor dengan kepentingan beragam dan mempunyai dimensi yang bermacam-macam, terdiri dari aktor lokal antara pemerintah dan oposisi, negara-negara Timur Tengah yang ikut terlibat, maupun internasional dengan keterlibatan Amerika Serikat dan Rusia. Kehancuran akibat perang saudara ini sangat parah. Setengah lebih penduduk Suriah mengungsi ke negara lain, sekitar 500.000 (lima ratus ribu) nyawa penduduk melayang, dan banyak dana dihamburkan untuk logistik perang. Rusia saja disebut-sebut menghabiskan sekitar US\$4 juta (sekitar Rp 50 miliar) setiap hari dalam perang selama 6 tahun ini, padahal jumlah negara yang terlibat banyak. Estimasi kerugian secara ekonomi dalam perang Suriah sekitar 255 Billion Euro menurut Euronews. Jika perdamaian kedua pihak terlaksana saat ini dan restorasi berjalan lancar, Suriah diperkirakan membutuhkan waktu 15 tahun untuk membangun ekonominya seperti sebelum perang. Sebenarnya kedua belah pihak yang bertikai, pemerintah dan oposisi sudah hampir habis tenaga dan logistiknya, tapi keduanya masih tampak gengsi dan mendapat tekanan dari negara donor. Ini menunjukkan betapa kompleksnya perang Suriah.

Kedua, keterlibatan ISIS (Islamic State in Iraq and Syria) dalam krisis politik di Irak dan Suriah. Peperangan di sub kawasan 
Timur Tengah antara pemerintah Irak dan Suriah dengan ISIS ini bertujuan menghabisi kekuatan teritorial ISIS di Suriah utara dan Irak utara. Usaha ini dilakukan untuk menguasai kembali Kota Mosul dan Kota Raqqa. Akhirnya usaha ini berhasil, pada 10 Juli 2017 Perdana Menteri Irak Haedar al-Abbadi mendeklarasikan bahwa Mosul sudah dibebaskan oleh pemerintah Irak, kemudian disusul Kota Raqqa yang dibebaskan oleh Tentara Suriah pada 10 Oktober 2017. Agenda bagi pemerintah Irak dan Suriah ke depan yang paling berat adalah mewujudkan perdamaian, rekonsiliasi, dan pemulihan yang membutuhkan waktu panjang serta diperkirakan memakan biaya yang sangat besar.

Ketiga, referendum yang dilakukan oleh masyarakat Kurdistan di bagian wilayah Timur Laut Irak pada 25 September 2017. Peristiwa ini memicu konflik politik dan kontak senjata antara pemerintah Turki, Iran, dan Suriah dengan masyarakat suku Kurdi. Hal ini karena suku Kurdi berada di tiga negara tersebut. Persoalan ini menjadi bom waktu yang paling berbahaya dalam kurun waktu terakhir ini di wilayah bagian Arab Timur, karena kedua pihak sama-sama ngotot; pihak Kurdistan menginginkan kemerdekaan dan tiga negara tersebut menolaknya. Problemnya, Kurdistan saat ini memiliki kemampuan militer dan semangat yang tinggi untuk mewujudkan kemerdekaannya, sehingga upaya damai dari Baghdad, Ankara, dan Teheran sangat ditunggu untuk menyelesaikan krisis politik di kawasan ini.

Keempat, krisis politik yang melibatkan Arab Saudi dan Bahrain dengan Qatar, kemudian diikuti oleh Uni Emirat Arab, serta Mesir yang memutuskan hubungan diplomatik dengan Qatar pada hari Senin, 5 Juni 2017. Negara-negara tersebut mengambil langkah tersebut dengan alasan Qatar telah mendukung aksi terorisme. Berbagai upaya dilakukan untuk mendamaikan kedua belah pihak, namun semuanya gagal.

Selain krisis politik yang disebabkan karena konflik antar negara-negara yang ada di Timur Tengah, konflik juga terjadi dalam internal mereka antara pemerintah dan oposisi. 
Terjadinya gerakan turun ke jalan untuk menentang pemerintah meledak di Mesir, Sudan, Libia, Irak, Suriah, Tunisia dan Yaman, serta di beberapa negara lain di Timur Tengah.Bahkan dalam menyikapi perkembangan politik dan sebagai upaya untuk meredam gejolak di negaranya, beberapa pemimpin negara mengumumkan keinginannya untuk tidak mencalonkan diri lagi setelah masa jabatannya berakhir. Presiden Sudan Omar al-Bashir mengumumkan ia tidak akan mencalonkan diri lagi pada 2015, begitu pula Perdana Menteri Irak Nouri al-Maliki, yang masa jabatannya berakhir tahun 2014, meskipun sikap politik ini juga belum bisa menjadi senjata ampuh untuk meredam unjuk rasa yang semakin menjadi-jadi menuntut pengunduran dirinya secepatnya (Jatmika, 2013: 161).

\section{Fundamentalisme dan Radikalisme di Timur Tengah}

Bangkitnya gerakan fundamentalisme dan radikalisme di Timur Tengah dewasa ini, secara historis tidak bisa dilepaskan dari reaksi atas maraknya gelombang modernitas yang membanjiri negara-negara Muslim umumnya, dan negara-negara Timur Tengah pada khususnya, pada awal abad ke-20. Reaksi atas munculnya modernitas ini bukan hanya pada dimensi kultural, tetapi juga dimensi struktural-institusional, seperti sains dan teknologi serta instrumen modern lainnya, khususnya pandangan mengenai kesadaran kebangsaan yang melahirkan konstruksi negara-bangsa modern. Reaksi tersebut muncul karena ketidakmampuan kultur masyarakat Timur Tengah dalam merespons nilai-nilai dan normanorma baru yang diusung gelombang modernitas tersebut.

Kondisi ini tentu saja membawa dampak serius, hadirnya idiologi nasionalisme di negara-negara Timur Tengah mengalami ketegangan yang tajam, bahkan terjadi perlawanan dari elemen masyarakat dan negara. Di samping realitas masyarakatnya yang sangat beragam, kondisi ini diperparah dengan adanya pertentangan konsepsi negara-negara sekuler modern dengan universalisme tatanan agama. Kondisi ini diperparah dengan adanya krisis yang 
dialami Negara-negara Timur Tengah sendiri, berikut adanya kelemahan-kelemahannya yang mendasar, serta kenyataan akan minimnya basis kultural bagi terbentuknya civil society modern di Timur Tengah. Fenomena ini telah mempertajam ketegangan dan benturan politik serta idiologi yang menghambat perkembangan kesadaran kebangsaan masyarakat Timur Tengah.

Fundamentalisme dan radikalisme agama di Timur Tengah dapat diklasifikasikan dalam beberapa kategori. Pertama, negaranegara yang rezim pemerintahnya otoriter seperti Irak dan Suriah. Al-Mujahidin di Irak menentang kediktatoran penguasa di Irak, demikian halnya al-Ikhwan di Suriah yang menentang rezim penguasa Basyar al-Asad. Kedua, wilayah yang dijajah dan diduduki kekuatan asing, seperti di Palestina. Radikalisme di Palestina muncul sebagai reaksi atas kekerasan politik yang dilakukan Israel di daerah Palestina yang diduduki. Agresi dan terorisme negara yang dimainkan oleh Israel terhadap penduduk Palestina dan usaha mencaplok beberapa wilayah di Jalur Gaza, Tepi Barat, Dataran Tinggi Golan dan beberapa wilayah lain. Ketiga, di negara yang kebijakan pemerintahannya dipandang terlalu memihak ke Barat seperti di Mesir. Munculnya Ikhwanul Muslimin di Mesir tidak lepas dari sentimen massa (Sharabi, 1988: 136), menentang kebijakan pemerintah yang pro-Barat dan cenderung memarjinalkan peran mereka.

Sementara fundamentalisme dan radikalisme di Tunis, MTI (Mouvement de Tendance Islamique) muncul karena sentimen massa terhadap kebijakan pemerintah Tunis yang menguntungkan Barat, mejauhkan agama dengan rakyat tunis. Kelompok ini, oleh pemerintah Tunis selain disebut sebagai radikalis, juga teroris dukungan Iran. Namun pemerintah Tunis sendiri akhirnya bisa digulingkan oleh Zainal Abidin bin Ali yang didukung oleh kaum radikalis di Tunis. Pergeseranpolitik di Tunis ke arah kebijakan garis keras yang dilakukan oleh para aktivis Islam tersebut dipengaruhi oleh beberapa peristiwa di Aljazair. Sejak lama, negara ini dikuasai oleh partai tunggal dan monolitik, di bawah rezim Presiden 
Chadli Bendjedid dari Front Pembebasan Nasional (FLN). Sejak kemerdekaannya, 1962 FLN menguasai setiap pemilu. Namun, pada 1990, Front Islamic du Salut (FIS) memenangkan pemilu Aljazair dengan mengantongi $55 \%$, sedangkan FLN hanya $32 \%$ ("The Middle East," 1990).

\section{Liga Arab dan Upaya Perdamaian di Timur Tengah}

Pada tanggal 3 Oktober 1998 beberapa artis terkenal dari negara-negara Arab, diantaranya: Ashalah, Ihab Taufiq, Diana Haddad, Abdul Majid Abdullah, Walid Taufiq dan lainnya menyanyikan lagu "Al-Hilm Al-A raby" di Libanon secara bersamasama dengan penuh harapan. Ini merupakan impian yang luhur, sekaligus cita-cita persatuan dan kebangkitan Arab. Namun ironisnya cita-cita ini datang dari para penyanyi dan belum tentu menjadi kenyataan dalam realita perpolitikan para pemimpin mereka. Hanya saja, setidak-tidaknya obsesi ini akan memberikan stimulasi bagi pemimpin Arab dan Timur Tengah untuk merealisasikan kebangkitannya dan mengembalikan masa kejayaan yang telah lama mereka inginkan.

Sebenarnya dengan munculnya konflik yang berkepanjangan itu, telah terbetik keinginan untuk menggalang kekuatan di bawah satu payung organisasi. Maka berdirilah Pan-Arabisme yang pada kemudian hari lebih dikenal dengan Liga Arab. Terbentuknya Liga Arab ini lebih merupakan kesadaran politik yang genuin, menolak intervensi asing dan melintasi batas agama, bahkan menolak pandangan yang fundamentalistik. Pencetusnya sendiri, Abdurrahman Al-Kawakibi (1849-1903) misalnya, selain mengecam despotisme Utsmani, juga mengemukakan sejumlah kelebihan-kelebihan bangsa Arab untuk menjadi pemimpin dunia. Menurutnya Liga Arab harus bisa menyatukan negara-negara yang berada pada batas-batas alam seperti Terusan Suez, Lembah Eufrat dan Tigris, Lautan India dan Lautan Tengah (Al-Aqqad, 1986: 65-67). 
Dalam identitas kolektif yang supra-nasional dan superordinat ini, ternyata terdapat identitas yang didukung oleh eksistensi negara-bangsa. Namun lagi-lagi mereka juga terbentur dengan problem etnisitas. Berdirinya organisasi Liga Arab mempunyai misi bukan hanya untuk menyatukan negara-negara Arab. Lebih dari itu, ia menjadi media dalam membangun peradaban Arab. Peradaban yang oleh Muhammad 'Abied al-Jabiri, disebut sebagai embrio peradaban Islam. Pada dasarnya keduanya mempunyai agenda yang sama, mencitrakan Arab, Timur Tengah dan dunia Islam sebagai peradaban alternatif, damai dan inklusif. ${ }^{1}$

Dalam upaya untuk menciptakan suasana kondusif, ada beberapa langkah yang perlu ditempuh terutama untuk menyelesaikan dilema politik yang terjadi di kawasan Timur Tengah. Diantaranya: Pertama, PBB harus menekan Israel agar selalu mematuhi perjanjian yang telah disepakati bersama. Kedua, Palestina sebaiknya tetap berjalan di atas jalur hukum dan mengupayakan diplomasi sampai proses perdamaian benar-benar terwujud. Ketiga, sikap proaktif pemimpin dunia, seperti Presiden Amerika Serikat, para pemimpin negara Arab dan negara Timur Tengah, untuk selalu mengupayakan jalan damai dan meyakinkan bahwa dengan cara kekerasan tidak akan menyelesaikan krisis politik di Timur Tengah. Keempat, hendaknya negara-negara di Timur Tengah tetap meminta dukungan dari negara muslim lainnya untuk menjaga kondusifitas kawasan Timur Tengah.

\section{E. Simpulan}

Kawasan Timur Tengah merupakan wilayah yang sarat dengan sejarah keemasan dan budaya masyhur, yang membentang mulai dari lembah Sungai Nil, Eufrat dan Tigris, serta wilayah lainnya. Bahkan negara-negara yang ada di Timur Tengah sering

${ }^{1}$ Muhammad 'Abied al-Jabiri mengajukan metode membangun peradaban Arab dengan melalui kritik wacana, seperti dalam "Trilogi Kritik Nalar Arab": Takwin al-Aql al-Araby (Konstruksi Nalar Arab), Bunyah al-'Aql al-'Arabi (Struktur Nalar Arab) dan al-'Aql as-Siyâsi al-'Arabi (Nalar Politik Arab). Setelah trilogi ini ia kemudian menyusuf buku keempatnya yang berjudul: Al-'Aql al-Akblâqi al-`Arabi. 
dijuluki negara para Nabi. Namun di kawasan Timur Tengah ini juga sering terjadi pertumpahan darah disebabkan adanya berbagai kepentingan politik baik itu kepentingan domestik, regional maupun internasional. Sering terjadinya konflik mulai dari Perang Arab Israel, Perang Irak-Iran, dan peperangan lain, sehingga kawasan ini juga disebut Arab Spring, karena adanya peperangan dalam dekade terakhir ini.

Konflik di Timur Tengah juga disebabkan karena faktor keberadaan kaum fundamentalis dan kaum radikalis di Timur Tengah. Di Afganistan, fragmentasi etnis menurunkan kemampuan para radikalis, sementara di Sudan, Aljazair dan Iran kaum radikalis justru berada dalam kekuasaan. Di Irak meletus ketegangan antara penguasa etnis Sunni dari klan Takrit dan Kurdi di satu sisi dan Syi’ah di sisi lain. Konflik juga terjadi antara mayoritas Sunni dan kaum Alawi di Suriah. Kaum radikalis mengekpresikan gerakan moral dan politiknya melalui sentimen massa terhadap ideologi nasionalis dan sosialis. Bahkan sentimen massa ini akhirnya melembaga, baik formal maupun informal. Kita bisa mengamati gerakan radikalisme yang terbentang di kawasan Timur Tengah, seperti Ikhwanul Muslimin (Mesir), FIS (Aljazair), Refah (Turki), Jamaat Islami (Pakistan), Hizb at-Tahrir (Yordania), Taliban (Afghanistan), AlMujahidin (Irak), Jam'iyah Ruhaniyah Mobarez (Iran), Hizbullah (Libanon), Hammas (Palestina), Gerakan Imam Mahdi (Arab Saudi), Hizb an-Nahdlah (Tunisia), al-Ikhwan (Suriah), National Islamic Front/NIF (Sudan), al-Haq (Yaman), Arab Revolutionary Brigades (Kuwait) dan Munadzdzamat al-Amal al-Islami (Bahrain).

Oleh karena itu, agenda yang paling penting dilakukan oleh seluruh lapisan yang ada di Timur Tengah adalah menepis isu tentang benturan peradaban yang memposisikan Islam sebagai penghalang Barat. Hal ini karena ketika Samuel Huntingtonmembuat tesis tentang benturan peradaban,maka peradaban Islam yang hanif justru mengambil peran strategis, memprakarsai perdamaian dunia dengan mengakomodir antar-peradaban berdasarkan saling menghormati, saling mengakui dan egaliter. 


\section{DAFTAR PUSTAKA}

Abdurrahman, D. (2007). Metodologi Penelitian Sejarah. Jogjakarta: Ar-Ruz Media.

Abdurrahman, M. (2003). Geliat Irak Menuju Era Pasca Saddam. Jakarta: Penerbit Kompas Media Nusantara.

Al-'Aqqad, A. M. (1986). Arrahalah Abdurrahman al-Kawakibi. Cairo: Dar Nahdhah Mishr li at-Tabaah wa an-Nashr.

Al-Jabiri, M. A. (1996). Addîn wa ad-Daulah wa Tathbîq as-Syarîah. Markaz Dirâsah al-Wihdah al-'Arabiyah.

Al-Qardawi, Y. (1980). al-Hulûl al-Mustauradah Waqâif Janât 'ala Ummatina. Beirut: Muassasah a-Risâlah.

Armstrong, K. (2001). The Batle for God, (Terj. Satrio Wahono dke..) Berperang Demi Tuhan. Bandung: Mizan.

Azra, A. (1996). Pergolakan Politik Islam; dari Fundamentalisme, Modernisme hingga Post-Modernisme. Jakarta: Paramadina.

Bannerman, P. (1988). Islam and Perspective: A Guide to Islamic Society, Politics and Law. London: Routledge.

Binder, L. (1961). Religion and Politics in Pakistan. Berkeley and Los Angeles: The University of California Press.

Giddens, A. (1987). The Nation-State and Violence. Berkeley: University of California Press.

Jatmika, S. (2013). The Arab Spring 2010: Puncak Gunung Es Krisis Politik di Kawasan Timur Tengah. Jurnal Hubungan Internasional, 2(2).

Kasdi, A. (2001). Membangun Peradaban Umat; Perspektif Sosial, Politik dan Humanisme dalam Islam. Cairo: Lakpesdam Mesir.

Kasdi, A. (2002). Fundamentalisme Islam Timur Tengah: Akar Teologi, Kritik Wacana dan Politisasi Agama. Jurnal Tashwirul Afkar, (13).

Lenezowski, G. (1993). The Middle East in World Affairs (Terj. Asgar Bixby), Timur Tengah di Tengah Kancah Dunia. Bandung: Sinar Baru Al-Gesindo. 
Lipson, L. (1993). The Ethical Crises of Civilization: Moral Melthdown or Advance. Newbury and London: Sage Publication.

Moris, M. E. (1997). Water and Conflict in the middle East: Threats and Opportunities; Studies in Conflict \& Terrorism, 20.

Muhajir, N. (1994). Metodologi Penelitian Kualitattif. Yogyakarta: Rieke Sarasin.

Neuman, W. L. (1997). Social Methods, Qualitative and Quantitative Approachs. Buston: Ally and Bacon.

Rahman, F. (1979). Islam and Modernity, An Intelectual Transformation. Minneapolis: Bibliotheca Islamica.

Ruslin, I. T. (2013). Memetakan Konflik di Timur Tengah; Tinjauan Geografi Politik. Jurnal Politik Profetik, 1(1).

Sahrasad, H., \& al-Chaidar. (2017). Fundamentalisme, Terorisme dan Radikalisme; Perspektif atas Agama, Masyarakat dan Negara. Jakarta: Freedom Foundation.

Sharabi, H. (1988). Nepatriarchy: A Theory of Distorted Change in Arab Society. New York: Oxford University Press.

Sihbudi, R. (2007). Menyandera Timur Tengah. Bandung: Mizan.

Starr, J. (1992). Water Politics in the Middle East. Majalah Middle East.

Sugiono. (2008). Metode Penelitian Pendidikan: Pendekatan Kuantitatif, Kualitatif, dan R $\approx D$. Bandung: Alafabeta.

Sya’ban, M. (1998). Al-Ahram.

Taylor, A. R. (1988). The Islamic Question in Middle East Politics. London: Westview.

The Middle East. (1990).

Tibi, B. (1988). The Crisis of Modern Islam: A Preindustrial Culture in The Scientific: Technological Age. Salt Lake City: The University of Utah Press.

Tibi, B. (2000). The Challenge of Fundamentalisme: Political Islam and the New World Disorder, (Terj. Imron Rosyidi, dkk.), Ancaman Fundamentalisme Islam. Yogyakarta: Tiara Wacana. 
